\title{
The high cost of being an (aspiring) medical student
}

$\mathrm{T}$ he $\$ 113000$ I will owe the National Bank after 4 years of medical school doesn't phase me one iota. Partly because this amount is actually below the average, ${ }^{1}$ but more importantly because I know I'm making a secure investment — and I had help. My faculty's policy on student financial support - ubiquitous among Canadian medical institutions - affirms that no student offered admission will be unable to enter or to complete the program for financial reasons. Well said. Scholarships and bursaries abound for those who cannot foot the bill. Coupled with government assistance and professional lines of credit, costs can be met in exchange for a debt that is manageable and usually repaid within a few years.

Medicine's elitist reputation is mostly historic; anyone can afford to attend medical school.

But what about those who can't afford to apply?

While the cost of being a medical student is met, the cost of being a medical applicant is not. Allow me to provide a (free) estimate. Applying to the 6 medical schools in Ontario costs $\$ 660$. Toss in Alberta, British Columbia, Quebec (McGill, for us AngloCanadians) and the east, and suddenly the cost climbs to well over $\$ 1000$. Most medical schools arrange for interviewers to billet with current medical students, but for interviewees, transportation alone can easily double the amount mentioned above.

Although some institutions are now waiving the Medical College Admission Test (MCAT) prerequisite, most still require students to fork over the $\$ 210$ sitting cost and to write the test.

The buck doesn't stop there. Anyone taking this test seriously is going to spend at least $\$ 100-\$ 200$ on study material. And a growing number of students who seek to out-compete their peers are taking summer-long preparatory courses. The going rate for classroom-style preparation course is $\$ 450-\$ 1700$. One-on-

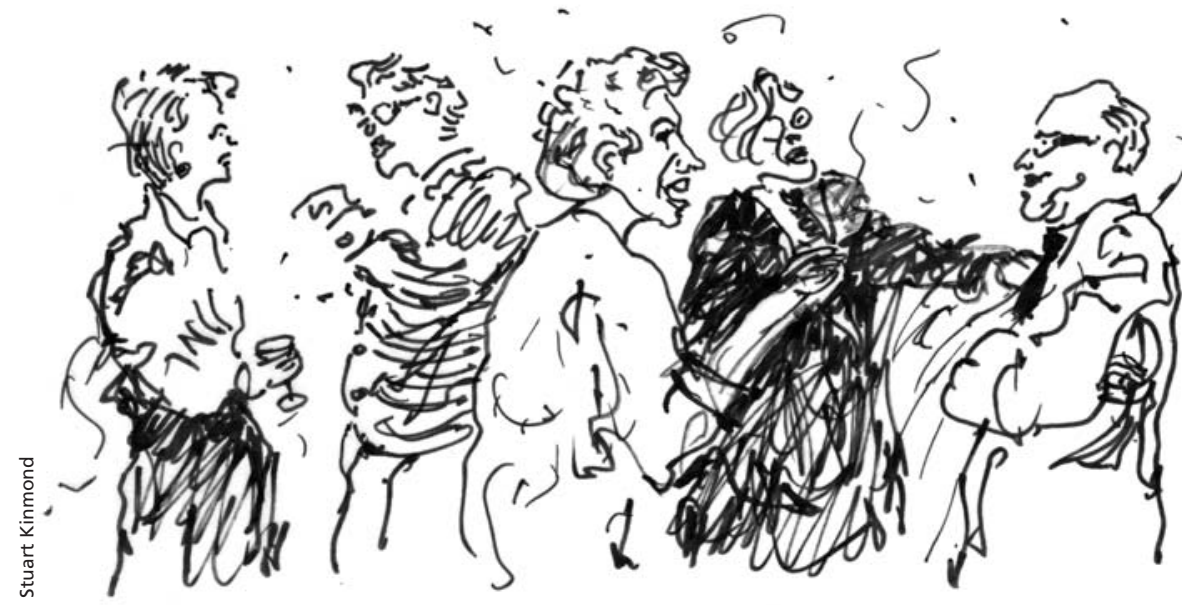

one help can be purchased at a rate of \$75-\$110 per hour. Recently in Toronto, The Princeton Review, a popular test preparation company, launched the "Ultimate MCAT" - a 6-week day and evening boot camp. ${ }^{2}$ For a tuition and residence cost of $\$ 10000$, the aspiring applicant is essentially forced to get the scores they need.

As much as I don't like to admit it, these courses work - for those who can afford to pay.

In addition to all these expenses, increasing numbers of students are deciding to forgo a job and devote their entire summer to MCAT preparation, thus they lose this income.

Application costs stretch the finances of many undergraduates. (I needed a \$1000 bursary from my grandparents.) For those without benefactors, the options are limited. Frugal applicants can put themselves at a disadvantage; without meeting a large upfront cost, the pre-med student is at risk of having lower quantity and quality of test-preparation hours, as well as a reduced number of schools on the receiving end of their application.

There is, however, a solution. The Association of American Medical Colleges has a fee assistance program for US citizens who require financial assistance to write the MCAT and apply. ${ }^{3}$ Canada's provincial application systems should consider adopting a similar ini- tiative. Our made-in-Canada stamp could also include providing funding (such as travel expenses) for applicants from underserviced areas, with the hope that they may end up practising in their home community.

The Ontario Medical School Application Service and the 17 Canadian medical schools need to be part of the solution. With no guaranteed return on investment, the less fiscally fortunate often cannot afford to be competitive applicants — or applicants at all.

\section{Alexander N.J. White \\ Medical student \\ Class of 2012 \\ University of Toronto \\ Toronto, Ont.}

\section{REFERENCES}

1. Kondro W. Debt woes. CMAJ 2007; 176:918.

2. The Princeton Review. MCAT Test Preparation. Princeton (NJ): The Review; 2008. Available: www .princetonreview.com/medical/mcat-test-preparation aspx?uidbadge $=\% 07$ (accessed 2008 Oct 15).

3. Association of American Medical Colleges. About the fee assistance program (FAP). Washington: The Association; 2008. Available: www.aamc.org /students/applying/fap/aboutfap.htm (accessed 2008 Oct 15).

Have you got an opinion about this article? Post your views at www.cmaj.ca. Potential Salon contributors are welcome to send a query to salon@ cma.ca. 